\title{
Growth and Flowering Responses of Matthiola incana L. R. BR. to Paclobutrazol
}

\author{
Ron Ecker, Amalia Barzilay, Levy Afgin, and \\ Abd-elrahem A. Watad \\ Department of Ornamental Horticulture, Agricultural Research \\ Organization, The Volcani Center, POB 6, Bet-Dagan, 50 250, Israel
}

Additional index words. growth retardants, flower senescence

Matthiolu incana is an annual-biennial ornamental crop, widely used throughout the world for fresh flowers and gardens. None of the cultivars is compact enough for use as a flowering potted plant. The objective of this study was to determine the effect of substrate drench with 1-(4-chlorophenyl)-4,4dimethyl-2(1 $H$-1,2,4-triazol-1-yl)pentan301 (paclobutrazol) on the growth and flowering of potted $M$. incana seedlings.

We used 'Midget-red' (Takii's, Kyoto, Japan), an early flowering, short cultivar and 'Lavender' (Van-Egmond's, Leiderdrop, Holland), a late-flowering, medium-stature cultivar.

Seeds were sown in a plastic greenhouse on 18 Jan. 1991. Seedlings (20 days old) were potted in 12-cm-diameter (1.2-liter) pots, containing 2 coarse sand : 1 peat substrate $(\mathrm{v} / \mathrm{v})$. Plants were grown outdoors and fertigated daily with $50 \mathrm{mg}$ N/liter from $20 \mathrm{~N}$ $9 \mathrm{P}-16 \mathrm{~K}$. Both cultivars were treated with paclobutrazol 20 days after potting. 'MidgetRed' was at first-bud-appearance stage when treated, while 'Lavender' was vegetative. Paclobutrazol solutions were applied as a substrate drench, using $50 \mathrm{ml} /$ pot that supplied $0.25,0.5$, or $2.0 \mathrm{mg}$ paclobutrazol/pot. Control plants were not treated. Data taken included stem (below inflorescence) and inflorescence lengths and flowering date. The percentage of flowers senesced within each inflorescence (one inflorescence per plant) of 'Midget-Red' was recorded 30 days after the beginning of anthesis. The design included four replicates (single potted plants) for each treatment and four replicates for the control (untreated plants), arranged in four randomized blocks. Data were subjected to linear, quadratic, and cubic regression analyses (control plants were included as $0.0 \mathrm{mg}$ paclobutrazol/pot).

\footnotetext{
Received for publication 3 Apr. 1992. Accepted for publication 17 Aug. 1992. Contribution from the Agricultural Research Organization, The Volcani Center, Bet-Dagan, Israel. No. 3370-E. 1991 series. The cost of publishing this paper was defrayed in part by the payment of page charges. Under postal regulations, this paper therefore must be hereby marked advertisement solely to indicate this fact.
}

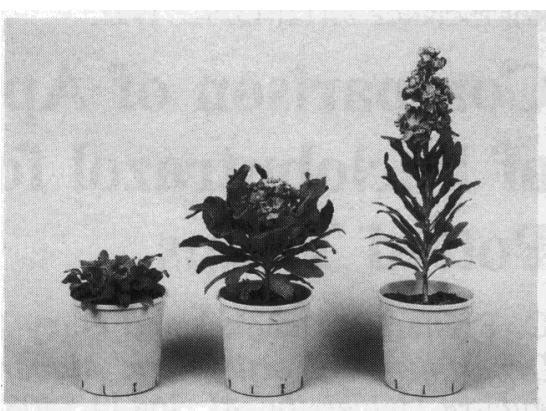

Fig. 1. Representative potted plants of Matthiola incana 'Lavender' at full flowering stage, 53 days after treatment, with paclobutrazol applied by substrate drench: control (right), $0.50 \mathrm{mg} /$ pot (center), $2.00 \mathrm{mg} /$ pot (left).
The time from potting to flowering of 'Lavender' was prolonged by increasing the level of paclobutrazol (Table 1). The time of flowering of 'Midget-Red' was not influenced by paclobutrazol, apparently because treatments were applied after the appearance of flower buds. Paclobutrazol did not delay flowering of other plants (Cox and Keever, 1988; Hamada et al., 1990).

Increasing the dose of paclobutrazol reduced the stem length of 'Lavender' but not of 'Midget-Red' (Table 1). However, inflorescence length of both cultivars was reduced with increasing paclobutrazol doses (Table 1). A substrate drench of 0.5 or 2.0 $\mathrm{mg} /$ pot altered the entire plant morphology and structure (foliage and inflorescence) to a thicker and more compact plant (Fig. 1). Similar growth-retarding effects of paclobutrazol were reported for other plant species (Gilbertz, 1992; Hamada et al., 1990). Increasing the paclobutrazol level caused a decrease in the percentage of senesced flowers of 'Midget-Red' recorded 30 days after the onset of flowering (Table 1). A similar response was observed in 'Lavender' (data not shown). Halevy and Wittwer (1966) reported that chloromequat and daminozide growth retardants delayed senescence in other flowers.

The present results indicate that paclobutrazol-treated $M$. incana potted plants with a compact inflorescence and prolonged postproduction life are a potential new marketable product. A medium drench treatment of $0.5 \mathrm{mg} /$ pot seems to produce the most commercially desirable plants.

\section{Literature cited}

Cox, D.A. and G.J. Keever. 1988. Paclobutrazol inhibits growth of zinnia and geranium. HortScience 23:1029-1030.

Gilbertz, D.A. 1992. Chrysanthemum response to timing of paclobutrazol and uniconazole sprays. HortScience 27:322-323.

Halevy, H.A. and S.H. Wittwer. 1966. The effect of growth retardants on longevity of vegetables, mushrooms and cut flowers. Proc. Amer. Soc. Hort. Sci. 66:582-590.

Hamada, M., T. Hosoki, and T. Maeda. 1990. Shoot length control of tree-peony (Paeonia suffruticosa) with uniconazole and paclobutrazol. HortScience 25:198-200.
Table 1. Effects of substrate drench of paclobutrazol on growth and flowering of an early flowering ('Midget-Red') and late-flowering ('Lavender') cultivar of Matthiola incana.

\begin{tabular}{|c|c|c|c|c|}
\hline $\begin{array}{l}\text { Cultivar and } \\
\text { paclobutrazol } \\
\text { applied } \\
\text { (mg/pot) }\end{array}$ & $\begin{array}{l}\text { Days from } \\
\text { potting to } \\
\text { flowering }\end{array}$ & $\begin{array}{l}\text { Stem } \\
\text { length } \\
(\mathrm{cm})\end{array}$ & $\begin{array}{l}\text { Inflorescence } \\
\text { length } \\
(\mathrm{cm})\end{array}$ & $\begin{array}{c}\text { Flowers } \\
\text { senesced } \\
\text { after } 30 \text { days } \\
(\%)\end{array}$ \\
\hline \multicolumn{5}{|l|}{ Lavender } \\
\hline 0.00 & 47.5 & 21.8 & 16.5 & \\
\hline 0.25 & 47.2 & 8.0 & 17.0 & \\
\hline 0.50 & 56.3 & 5.4 & 9.3 & \\
\hline 2.00 & 70.8 & 4.2 & 1.5 & \\
\hline Linear reg. & $* * *$ & $* * *$ & $* * *$ & \\
\hline Quadratic reg. & NS & $* * *$ & NS & \\
\hline Cubic reg. & NS & $* *$ & NS & \\
\hline \multicolumn{5}{|l|}{ Midget-Red } \\
\hline 0.00 & 31.7 & 10.5 & 14.7 & 67.0 \\
\hline 0.25 & 31.2 & 12.0 & 6.5 & 12.5 \\
\hline 0.50 & 32.5 & 12.4 & 5.6 & 8.7 \\
\hline 2.00 & 32.0 & 11.5 & 2.7 & 0.0 \\
\hline Linear reg. & NS & NS & $* * *$ & * \\
\hline Quadratic reg. & NS & NS & ** & NS \\
\hline Cubic reg. & NS & NS & NS & NS \\
\hline
\end{tabular}

NS,*,*****Nonsignificant $(P>0.05)$ or significant at $P<0.05,0.01$, or 0.001 , respectively. 